УДК 342.922

DOI https://doi.org/10.32849/2663-5313/2020.1.20

\title{
Павло Комірчий,
}

канд. юрид. наук, дочент,

докторант кафедри публічного управління та адміністрування

Національної академії внутрішніх справ

\section{ОРГАНІЗАЦИЙНО-ПРАВОВА СТРУКТУРА КАДРОВОГО ЗАБЕЗПЕЧЕННЯ ПУБЛІЧНОЇ СЛУЖБИ В ПРАВООХОРОННІЙ СФЕРІ}

У статті вперше виокремлюються, систематизуються та комплексно аналізуються нормативні вимоги до організачійної структури кадрового забезпечення публічної служби у правоохоронній сфері Украйни, тобто організачійні нормативні вимоги до відповідного кадрового забезпечення. Автор визначає місце цих організачійних вимог у загальній структурі нормативних вимог до кадрового забезпечення публічної служби у відповідній сфері, а також виокремлює й систематизує їх крізь призму останніх змін в адміністративному законодавстві України, зумовлених процесом «перезавантаженням влади» у 2019 рочі та новим етапом реформи правоохоронної системи нашої держави. У висновках узагальнюються отримані результати дослідження. Визначено, що організачійна структура кадрового забезпечення публічної служби у правоохоронній сфері України - ие елемент управління кадрами органів публічної служби у сфері правоохорони, що є нормативно упорядкованою системою взаємопов'язаних елементів, які знаходяться між собою у стійких адміністративно-правових відносинах стосовно кадрового забезпечення, в межах яких забезпечується їх функиіонування як єдиного иілого. Зроблено висновок, що кадрове забезпечення публічної служби в правоохоронній сфері Украйни, власне як і будь-який інший складний сочіально-правовий феномен у площині функиіонування суб'єктів публічної адміністрачї̈, підлягає ретельному адміністративно-правовому врегулюванню, в межах якого нормотворием визначаються особливі правові вимоги до здійснення кадрового забезпечення публічної служби відповідної сфери. Тобто до існування кадрового забезпечення публічної служби в правоохоронній сфері у статичному та динамічному вигляді на нормативному рівні висувається велика кількість вимог, спрямованих на належне укомплектування суб'єкта публічної адміністраиї̈ якісними кадрами, уможливлення ефективного та рачіонального керування кадровим забезпеченням й підвищення рівня однозначності цвого явища. Особливе місие серед чих нормативних вимог займають нормативні вимоги до організачійної структури кадрового забезпечення публічної служби у правоохоронній сфері.

Ключові слова: кадри, кадрове забезпечення, правоохоронний орган, публічна служба, публічне адміністрування.

Постановка питання. Починаючи з вересня 2019 року в Україні активізувались численні перетворення у структурі системи суб'єктів публічної адміністрації та в самій концепції здійснення публічного адміністрування, що було ознаменовано здійсненням численних реформ, які отримали назву «перезавантаження влади» (державної служби загалом, а також органів прокуратури, Державного бюро розслідувань, судових органів). Примітним $€$ те, що ці зміни відновили процеси призупинених фундаментальних перетворень у системі цілей та цінностей суспільного розвитку, що закономірним чином призвело до відповідних нових фундаментальних змін у структурі та характері загроз означеному розвиткові. Не є виключенням із цього правила також і справедливі намагання сьогочасної України впровадити комплекс перетворень у сфері публіч- ного адміністрування у правоохоронній сфері, які, як і попередні зміни, «викликали до життя низку факторів протидії розгортанню новітнім ліберальним тенденціям» [1, с. 70]. Загострює цю проблему не завжди ефективна діяльність публічних службовців у правоохоронній сфері, що переважною мірою пов'язано з тим, що у відповідних органах публічної служби нашої держави не завжди на належному рівні здійснюється процес кадрового забезпечення. Ускладнює вирішення цього питання той факт, що в сучасній юридичній думці не існує узгодженого розуміння кадрового забезпечення, кадрового забезпечення публічної служби в правоохоронній сфері та нормативних вимог до здійснення кадрового забезпечення.

Важливість окресленої проблеми виявляється в соціально-правовій значимості кадрового забезпечення публічної служби, адже 
в загальному розумінні поняття «кадрове забезпечення» можна інтерпретувати в якості окремої галузі (напряму) кадрової політики, що підпорядкована меті відповідної політики та органічно взаємопов'язана з іншими іï галузями. При цьому в межах системного підходу поняття «кадрове забезпечення публічної служби у правоохоронній сфері України» слід розуміти в якості комплексного поняття, яким позначається: (1) галузь кадрової політики, що має системний характер, власну структуру, принципи та функції, безпосередньо спрямовані на діяльність і процес із належним чином здійснюваним укомплектуванням органів публічної служби у сфері правоохорони професійно підготовленими, кваліфікованими кадрами з урахуванням особливостей проходження служби у відповідних органах; (2) нормативно врегульована, особлива та цілеспрямована управлінська діяльність уповноважених осіб у структурі органів публічної служби у сфері правоохорони та процес і сукупність відносин, у межах яких реалізовується комплекс форм, методів, процедур і заходів уможливлення належного функціонування органів публічної служби у правоохоронній сфері шляхом вчасного та оптимального укомплектування цих органів якісними кадрами.

Відтак можемо дійти закономірного висновку, що кадрове забезпечення публічної служби у правоохоронній сфері України, будучи особливим напрямком кадрової політики та складною управлінською діяльністю, процесом, сукупністю правовідносин $з$ укомплектування органу належними кадрами, є досить складним феноменом, що безпосереднім чином впливає на ефективність діяльності відповідних органів публічної служби, а відтак - на охорону правопорядку, прав і законних інтересів людини i громадянина, суспільства та держави. При цьому відповідний результат досягається лише за умови, коли кадрове забезпечення публічної служби у правоохоронній сфері буде належним чином унормованим, а в практичній дійсності це забезпечення буде здійснюватися у відповідності до цих нормативних вимог.

Аналіз наукової літератури та невирішені питання. Тією чи іншою мірою кадрове забезпечення публічної служби в правоохоронній сфері України та вимоги до здійснення цього кадрового забезпечення критично аналізувались у наукових працях В.Б. Авер'янова, С.О. Андренко, О.М. Бандурки, О.В. Василєвої-Керян, В.М. Вац, О.М. Вольської, М.М. Дивака, Т.Є. Кагановської, М.В. Панченка та інших вітчизняних правників. Поряд із тим слід констатувати той факт, що останні зміни в чинному законодавстві зумовлюють потребу в переосмисленні кадрового забезпечення публічної служби загалом та публічної служби у сфері правоохорони, зокрема. Крім того, розвиток теорії публічної служби у відповідній сфері потребує структурованого універсального підходу до розуміння кадрового забезпечення цієї публічної служби та нормативних вимог до означеного процесу.

Окремо слід звернути увагу на той факт, що сьогодні в нашій державі не опубліковано систематизованих досліджень організаційних нормативних вимог до відповідного кадрового забезпечення, що є неприпустимим. Важливість цієї проблеми пояснимо тим, що вирішення нагальних проблем функціонування публічної служби в правоохоронній сфері можливо здійснити оптимальним шляхом лише завдяки підвищенню ефективності кадрового забезпечення правоохоронних органів. При цьому досягнення цього результату уможливлюється лише в разі, коли в чинному законодавстві будуть закріплені ефективні вимоги до організаційної структури кадрового забезпечення публічної служби у правоохоронній сфері.

Метою цієї наукової розвідки є виявлення та структурування нормативних вимог до організаційної структури кадрового забезпечення публічної служби у правоохоронній сфері нашої держави. Досягнення цієї мети виявляється можливим шляхом вирішення таких завдань: (1) уточнити загальну юридичну сутність нормативних вимог до кадрового забезпечення публічної служби у сфері правоохорони України, а також визначити основні групи цих нормативних вимог; (2) визначити місце нормативні вимоги до організаційної структури кадрового забезпечення публічної служби у правоохоронній сфері в структурі нормативних вимог до кадрового забезпечення публічної служби у відповідній сфері; (3) виокремити та систематизувати організаційні нормативні вимоги до кадрового забезпечення публічної служби у сфері правоохорони у світлі останніх змін в адміністративному законодавстві України, зумовлені процесом т. зв. «перезавантаженням влади» у 2019 році та новим етапом реформи пра| воохоронної системи нашої держави.

Виклад основного матеріалу. Спершу слід зазначити, що під поняттям «нормативні вимоги до кадрового забезпечення публічної служби у сфері правоохорони України» ми пропонуємо розуміти положення чинного адміністративного законодавства, доктри- 
нальні норми теорії права, адміністративного права та теорії публічного адміністрування, які у своїй сукупності, з одного боку, зумовлюють нормативне розуміння кадрового забезпечення публічної служби в правоохоронній сфері, а з іншого боку - безпосередньо впорядковують правові відносини та процеси, зумовлені цими відносинами, щодо укомплектування публічної служби у сфері правоохорони кадрами та легального впливу на ці кадри повноважних суб'єктів кадрового забезпечення.

У концептуальному сенсі відповідні вимоги $є$ комплексом норм (стандартів) спрямованих на врегулювання кадрового забезпечення публічної служби в правоохоронній сфері нашої держави, становлячи нормативну основу (підставу) для об'єктивації цього кадрового забезпечення. У цьому сенсі відповідні нормативні вимоги можуть бути поділені щонайменше на такі групи нормативних вимог: 1) засадничі нормативні вимоги (вимоги, що: корегують мету кадрового забезпечення; визначають завдання цього забезпечення; формують принципи кадрового забезпечення); 2) кадрово-статусні нормативні вимоги (вимоги до рівня правосуб'єктності: осіб, що можуть вступити на публічну службу у сфері правоохорони; публічних службовців, що можуть просуватись по службі у правоохоронній сфері; публічних службовців, до яких може застосовуватись заохочення; публічних службовців, що можуть притягуватись до дисциплінарної та матеріальної відповідальності); 3) прочесуальні нормативні вимоги (виявляються у сукупності різних порядків здійснення процедур кадрового забезпечення у правоохоронній сфері); 4) організачійні нормативні вимоги. У межах цієї наукової розвідки наша увага буде присвячена визначенню юридичної сутності саме організаційних нормативних вимог кадрового забезпечення публічної служби в правоохоронній сфері України. 3 огляду на це зазначимо, що вказана група нормативних вимог до кадрового забезпечення охоплює ті вимоги, що закріпленні в законодавстві нашої держави та стосуються інституційно-компетентісних вимог відносно здійснення кадрового забезпечення. Іншими словами, ці нормативні вимоги виявляються у вимогах чинного законодавства, спрямованих на упорядкування організації кадрової роботи публічної служби у сфері правоохорони.

У процесі з'ясування та виокремлення досліджуваних нормативних вимог необхідно проаналізувати те, яким саме чином у науковій літературі окреслюється організаційна структура. Наприклад, українські науковці І.Д. Падерін та Є.Е. Новак вважають, що «організаційна структура» - це «впорядкована сукупність взаємопов'язаних елементів, що знаходяться між собою у стійких взаємостосунках, які забезпечують їх функціонування i розвиток як єдиного цілого» [2, с. 137]. Н.С. Муромець і А.А. Черненко вважають, що «організаційна структура» $є$ елементом системи управління підприємством (установою, організацією), який являе собою «сукупність впорядкованих підрозділів різних рівнів управління, що взаємопов'язані між собою, метою функціонування яких є забезпечення ефективного управління підприємством» [3, с. 96].

Таким чином, можемо дійти думки, що організачійна структура кадрового забезпечення публічної служби у правоохоронній сфері України - це елемент управління кадрами органів публічної служби у сфері правоохорони, що є нормативно упорядкованою системою взаємопов'язаних елементів, що знаходяться між собою у стійких адміністративно-правових відносинах стосовно кадрового забезпечення, в межах яких забезпечується їх функціонування як єдиного цілого.

Українська вчена Т.Є. Кагановська, аналізуючи організаційну структуру кадрового забезпечення, доходе думки, що: (1) ця структура кадрового забезпечення характеризує саме суб'єктний склад держорганів та відповідних посадових осіб, на яких покладене виконання відповідних функцій із кадрового забезпечення в державі; (2) організаційна структура у співвідношенні з функціональною структурою цього забезпечення дає можливість «визначити конкретний рівень та суб'єкта виконання відповідної функції, а також провести аналіз відповідності наданих йому повноважень рівню його компетенції та колу функцій, які він виконує»; (3) «аналіз вертикальних та горизонтальних зв'язків між суб'єктами кадрового забезпечення дозволяє визначити конкретний рівень та обсяг їх повноважень і вдосконалити систему зв'язків між ними, а також імплементувати сучасні форми та методи управління в їх діяльність»; (4) організаційна структура кадрового забезпечення надає можливість «чітко відокремити суб'єктів управління кадровим забезпеченням від об'єкта їх впливу»; (5) «встановлення конкретних суб'єктів кадрового забезпечення 3 визначенням їх функції у цьому процесі дозволяє прямо виявляти недоліки, порушення в кадровій роботі та винних у їх вчиненні [4, с. 22, 26].

Відтак зазначимо, що загальні організаційні нормативні вимоги до кадрового 
забезпечення публічної служби у правоохоронній сфері містяться в розділі III Закону України «Про державну службу», головним чином у ст. 18 цього Закону, в якій унормовуються загальні аспекти статусу служби управління персоналом державного органу (СУПДО). Зважаючи на вказану норму, можемо дійти думки, що законодавець у межах вказаної норми закріплює такі організаційні вимоги кадрового забезпечення: (1) в державному органі повинна утворюватися СУПДО; (2) СУПДО повинна забезпечувати здійснення керівником держслужби своїх повноважень; (3) СУПДО відповідає за реалізацію державної політики з питань управління персоналом у держоргані, добір персоналу, планування та організацію заходів із питань підвищення рівня професійної компетентності державних службовців, документальне оформлення вступу на державну службу, іï проходження та припинення, укладання та розривання контрактів про проходження державної служби, а також виконує інші функції, передбачені законодавством; (4) СУПДО в питаннях реалізації державної політики у сфері держслужби керується Конституцією України, Законом України «Про державну службу» та іншими законами України, міжнародними договорами, згода на обов'язковість яких надана Верховною Радою України, постановами національного Парламенту України, указами Президента України, актами Уряду України та Нацагентства України з питань держслужби (НАДС); (5) НАДС затверджує Типове положення про СУПДО.

Окреслені загальні організаційні нормативні вимоги додатково конкретизуються в типовому положенні про службу управління персоналом від 3 березня 2016 року, яке затверджене НАДС [5] (далі - Типове положення від 3 березня 2016 року), і зводяться до таких вимог:

(1) нормативні вимоги до форми СУПДО, що виявляються щонайперше в тому, що в держоргані, чисельність якого становить менше 10 осіб, обов'язки відповідної служби можуть бути покладені на одного з державних службовців цього органу. При цьому чисельність СУПДО визначається з розрахунку до 20 осіб на одного спеціаліста СУПДО. Зазначимо, що у спеціальних положеннях про служби управління персоналу вимоги до форми та структури служби регламентуються 3 урахуванням особливостей відповідного органу та його кадрових потреб, здійснюваної кадрової політики.

Наприклад, у відповідності до структури Офісу Генерального прокурора в структурі цього органу діє Департамент кадрової роботи та державної служби (до реформи прокуратури аналогічним структурним підрозділом у структурі ГПУ також був Департамент кадрової роботи та державної служби, що діяв у відповідності до положення, затвердженого Наказом ГПУ від 6 жовтня 2017 року № 282; станом на момент початку дії ОГП не опубліковано спеціального положення про Департамент кадрової роботи Офісу Генпрокурора). Зазначений Департамент Офісу Генпрокурора є самостійним структурним підрозділом, підпорядкованим Генпрокурору та очолюваним начальником, який має заступника, і складається з Управління роботи 3 кадрами (до складу входить відділ роботи з кадрами), а також Управління роботи з персоналом державної служби (складається з відділу роботи з персоналом державної служби та відділу штатів, обліку кадрів та мобілізаційної роботи);

(2) нормативні вимоги до призначення СУПДО, тобто норми, які відображають основні завдання служби. Головним чином, цими завданнями є: реалізація державної політики 3 питань управління персоналом у державному органі; забезпечення здійснення керівником державної служби своїх повноважень 3 питань управління персоналом; забезпечення організаційного розвитку державного органу; добір персоналу державного органу; прогнозування розвитку персоналу, заохочення працівників до службової кар'єри, підвищення рівня їхньої професійної компетентності; здійснення аналітичної та організаційної роботи з кадрового менеджменту; організаційно-методичне керівництво та контроль за роботою з персоналом у підпорядкованих територіальних органах; документальне оформлення вступу на державну службу, їі проходження та припинення.

Слід зазначити, що нормативні вимоги до призначення функціонування СУПДО закономірним чином більш конкретизовані в положеннях про СУПДО у сфері правоохорони. Наприклад, у Положенні про Департамент персоналу, організації освітньої та наукової діяльності Міністерства внутрішніх справ України (МВС) зазначається, що цей структурний підрозділ апарату МВС виконує такі завдання: забезпечення організаційно-методичного керівництва, контролю та координації роботи з персоналом, здійснення своєчасного добору персоналу для підрозділів апарату МВС, керівного складу територіальних органів, закладів, установ і підприємств, що належать до сфери управління МВС, головного органу військового управління Нацгвардії України, та за дорученням Міністра центральних органів виконавчої влади, діяльність яких спрямовується 
та координується Міністром; документальне оформлення вступу, проходження, припинення державної служби та трудових відносин із працівниками апарату МBC, керівниками закладів, установ і підприємств, що належать до сфери управління МBC; прогнозування розвитку персоналу, в тому числі формування резерву керівників, заохочення персоналу до службової кар'єри, підвищення рівня їхньої професійної компетентності, оцінювання та атестування; організація професійного навчання, підвищення кваліфікації, перепідготовки та післядипломної освіти персоналу для МВС, Національної гвардії України (НГУ); здійснення у МВС організаційно-штатних заходів з оптимального розподілу та ефективного використання наявної штатної чисельності персоналу для виконання покладених на МВС завдань та функцій, удосконалення структури і штатів підрозділів МВС з урахуванням міжнародного досвіду; організація освітньої та наукової діяльності вищих навчальних закладів зі специфічними умовами навчання, науководослідних установ, що належать до сфери управління МВС; здійснення аналітичної та організаційної роботи 3 питань управління персоналом апарату МВС, територіальних органів, закладів, установ і підприємств, що відносяться до сфери управління МВC, головного органу військового управління НГУ, та за дорученням Міністра центральних органів виконавчої влади, діяльність яких спрямовує і координує Міністр загальне методичне керівництво роботою з оформлення документів для призначення пенсій та отримання пільг колишніми працівниками міліції, службовцями апарату MBC, територіальних закладів, що належать до сфери управління МВС, звільненим зі служби, роботи, та членами іх сімей;

(3) нормативні вимоги стосовно змісту функиіонування СУПДО, тобто норми, які відображають основні завдання служби. Вказані нормативні вимоги закріплюються в межах регламентування функцій служби. При цьому звернемо увагу на те, що в Типовому положенні від 3 березня 2016 року, а саме в п. II.2 міститься 42 функції, які повинна виконувати служба, серед іншого: організовує роботу щодо розроблення структури державного органу; контролює розроблення посадових інструкцій державних службовців державного органу, які затверджує керівник державної служби, а також переглядає їх на відповідність встановленим законодавством вимогам; вивчає потребу в персоналі на вакантні посади в державному органі та вносить відповідні пропозиції керівнику державної служби і т. д. Ці та інші норма- тивні вимоги щодо змісту функціонування СУПДО містяться у спеціальних положеннях про ці служби;

(4) нормативні вимоги щодо меж правомочності здійснення СУПДО компетентної діяльності, тобто норми, якими закріплюється перелік прав цієї служби. Зазначимо, що в Типовому положенні про СУПДО від 3 березня 2016 року перераховується шість основних прав вказаної служби: спільно 3 іншими структурними підрозділами перевіряти і контролювати дотримання правил внутрішнього службового розпорядку, вимог законодавства про працю та державну службу в держоргані та здійснювати контроль за додержанням законодавства про працю в підпорядкованих організаціях; взаємодіяти зі структурними підрозділами державного органу, підпорядкованими організаціями, держорганами та органами місцевого самоврядування 3 питань, що належать до її компетенції; одержувати у встановленому законодавством порядку від посадових осіб та іншого персоналу держоргану та підпорядкованих організацій інформацію, матеріали та пояснення, необхідні для здійснення покладених на неї завдань; за погодженням із керівником держслужби брати участь у конференціях, семінарах, нарадах та інших заходах із питань управління персоналом та організаційного розвитку; на оброблення персональних даних фізичних осіб відповідно до законодавства з питань захисту персональних даних для виконання покладених на неї повноважень; за дорученням керівника державної служби представляти держорган в інших органах державної влади, органах місцевого самоврядування, підприємствах з питань, що належать до їі компетенції.

\section{Висновки}

Кадрове забезпечення публічної служби в правоохоронній сфері України, власне, як i будь-який інший складний соціально-правовий феномен у площині функціонування суб'єктів публічної адміністрації, підлягає ретельному адміністративно-правовому врегулюванню, в межах якого нормотворцем визначаються особливі правові вимоги до здійснення кадрового забезпечення публічної служби відповідної сфери. Тобто до існування кадрового забезпечення публічної служби в правоохоронній сфері у статичному та динамічному вигляді на нормативному рівні висувається велика кількість вимог, спрямованих на належне укомплектування суб'єкта публічної адміністрації якісними кадрами, уможливлення ефективного та раціонального керування кадровим забезпеченням й підвищення рівня однозначності цього 
явища (також - результатів його об'єктивного вияву). Особливе місце серед цих нормативних вимог займають нормативні вимоги до організаційної структури кадрового забезпечення публічної служби у правоохоронній сфері. Ця група вимог охоплює інституційнокомпетентнісні стандарти здійснення кадрового забезпечення, тобто імперативні критерії упорядкування організації кадрової роботи публічної служби у сфері правоохорони.

\section{Список використаних джерел:}

1. Комірчий П.О. Публічна служба в правоохоронній сфері та правоохоронна функція держави. Юридичний бюлетень. 2018. № 7, Ч. 2. С. 69-76.
2. Падерін І.Д., Новак Є.Е. Аналіз впливу зовнішніх та внутрішніх факторів на стратегії підприємств малого та середнього бізнесу. Економіч ний вісник Донбасу. 2015. № 3(41). С. 135-141.

3. Муромець Н.Є., Черненко А.А. Логістичні принципи побудови організаційної структури торговельного підприємства. Проблеми і перспективи розвитку підприємниитва. 2014. № 2(2). C. $95-100$.

4. Кагановська Т.Є. Адміністративно-правові засади кадрового забезпечення державного управління в Україні : автореф. дис. ... д-ра юрид. наук 12.00.07. Київ, 2012. 33 с

5. Про затвердження Типового положення про службу управління персоналом державного органу : Наказ НАДС від 03.03.2016 № 47. Офіиійний вісник Украӥни. 2016. № 27. Ст. 1091.

For the first time, the article identifies, systematizes and analyzes comprehensively the regulatory requirements for the organizational structure of the staffing of the public service in the law enforcement sphere of Ukraine, that is, the organizational regulatory requirements for the relevant staffing. The author defines these organizational requirements place in the general structure of the regulatory requirements for staffing the public service in the relevant field, and also identifies and systematizes them through the prism of the latest changes in the administrative legislation of Ukraine, due to the process of the so-called "Reloading of power" in 2019 and a new stage of reform of the law enforcement system in our state. Conclusions generalize the investigation results obtained. It is determined that the organizational structure of public service personnel in the law enforcement sphere of Ukraine is an element of management of personnel of public service bodies in the field of law enforcement, which is a normatively ordered system of interrelated elements, which are in stable administrative and legal relations with respect to human resources, in within which their functioning as a whole is ensured. It is concluded that the human resources of the public service in the sphere of law enforcement in Ukraine, as well as any other complex social and legal phenomenon in the sphere of functioning of the subjects of public administration, is subject to a careful administrative and legal regulation, within which the rulemaker defines special legal requirements to the provision of public service personnel of the relevant field. That is, the existence of human resources of the public service in the law enforcement sphere in a static and dynamic form at the regulatory level is a large number of requirements aimed at properly staffing the public administration with quality personnel, enabling effective and rational management of staffing level and improving this level of integrity. Particularly important among these regulatory requirements is the regulatory requirements for the organizational structure of public service personnel in the field of law enforcement.

Key words: law enforcement, public administration, public service, staff, staffing. 